\title{
Effect of Seasonal Variation in the Composition of Major and Trace Elements of Lake Chamo, Ethiopia
}

\author{
Adane Gebresilassie Hailemariam ${ }^{1}$, Belete Yilma Hirpaye ${ }^{2}$ \\ ${ }^{1}$ Chemistry Department, Dire Dawa University, Dire Dawa, Ethiopian \\ ${ }^{2}$ Chemistry Department, Arbaminch University, Arba Minch, Ethiopian
}

Email address:

adanegebre19@yahoo.com (A. G. Hailemariam), y.belete2@gmail.com (B. Y. Hirpaye)

To cite this article:

Adane Gebresilassie Hailemariam, Belete Yilma Hirpaye. Effect of Seasonal Variation in the Composition of Major and Trace Elements of Lake Chamo, Ethiopia. American Journal of Applied Chemistry. Vol. 5, No. 6, 2017, pp. 110-120. doi: 10.11648/j.ajac.20170506.14

Received: September 29, 2017; Accepted: October 10, 2017; Published: December 11, 2017

\begin{abstract}
Water samples was collected from five sampling sites namely; inlet-1, inlet-2, center, outlet-1 and outlet-2 of Lake Chamo. The concentration of certain major and trace metals $\mathrm{Na}, \mathrm{K}, \mathrm{Mg}, \mathrm{Ca}, \mathrm{Cr}, \mathrm{Co}, \mathrm{Ni}, \mathrm{Mn}$ and $\mathrm{Cu}$ were determined in the water within the two consecutive season winter (dry) and spring (wet) season using atomic absorption spectrometer (AAS) and flame photometer (FP). The results revealed that the dissolved metal concentration in water were, Na ranged from $18-22, \mathrm{Mg}$ 0.34-0.97, K 10-19, Ca 1.6 -5.5, Cr 0.61- 4.0, Co 1.50-3.8, Ni 0.78-1.10, Mn 1.01- 1.98 and $\mathrm{Cu} 0.53-1.20 \mathrm{mg} / \mathrm{L}$ in the winter season and in the spring season $\mathrm{Na}$ ranged from $12-17.5, \mathrm{Mg} 0.51-0.62, \mathrm{~K} \mathrm{10-13}$, Ca 1.5- 3.9, Cr 0.60- 1.20, Co 1.50- 3.80, Ni $0.78-1.10$, Mn 1.01-1.9 and $\mathrm{Cu} 0.50-0.78 \mathrm{mg} / \mathrm{L}$. the physicochemical values in the winter season were, $\mathrm{P}^{\mathrm{H}}$ ranged from $9.39-9.45$, TDS $815-910 \mathrm{mg} / \mathrm{L}$, conductivity $1746-1965 \mu \mathrm{S} / \mathrm{cm}$, temperature $25.5-27.6^{\circ} \mathrm{C}$, salinity $0.87-0.93 \mathrm{ppt}$, turbidity $21.59-28.21 \mathrm{NTU}$ and DO $6.37 \mathrm{mg} / \mathrm{L}-8.24 \mathrm{mg} / \mathrm{L}$ and in the next season (spring), $\mathrm{P}^{\mathrm{H}}$ ranged from $9.30-9.40$, TDS $865-$ $920 \mathrm{mg} / \mathrm{L}$, conductivity $1739-1960 \mu \mathrm{S} / \mathrm{cm}$, temperature $25.8-29^{\circ} \mathrm{C}$, salinity $0.81-0.87 \mathrm{ppt}$, turbidity $22.59-37.21 \mathrm{NTU}$ and DO $6.27 \mathrm{mg} / \mathrm{L}-8.24 \mathrm{mg} / \mathrm{L}$.
\end{abstract}

Keywords: Lake Chamo, Water, Physicochemical

\section{Introduction}

\subsection{Background}

Water is one of the most essential substances needed to sustain human life, animals, plants and other living things. Without water no life is possible on earth. Different types of water bodies differ on their depth, size and level of water it holds. Among the different water bodies, lakes are a large body of water surrounded by land, inhabited by various aquatic life forms. Many researchers up on their studies on the level of trace elements in organisms inhabiting in lakes and other water bodies provide information on the status of the aquatic environment and the biota residing in them. [1]

As rivers drain in to lake, monitoring of the quality of river's water play a great role in water resource and ecological management. The Abaya-Chamo drainage basin as a sub basin of Great Rift Valley Lakes system has been an area of rapid population growth and settlement. The water quality of Lake Chamo has been affected in the past decade resulting in the death of aquatic habitats and wild life like zebra due to toxic cyano-bacterial bloom and other toxic noxious gases caused by increased hypo-limnetic activity in the lake. [2]

Water has unique chemical and physical properties due to its polarity and hydrogen bonds which makes it is able to dissolve, absorb, adsorb or suspend many different compounds. In nature, water acquires metals from its surrounding and those arising from humans and animals as well as other biological activities. The occurrences of enhanced concentrations of heavy metals especially in sediments may be an indication of human induced perturbations rather than natural enrichment through geological weathering. Heavy metals are non-biodegradable and they persist in the environment and may become concentrated up to the food chain, leading to enhanced levels in liver and muscle tissues of fishes, aquatic bryophytes and aquatic biota [3-5].

The state of trace metals in aquatic environment has been the focus of interest of chemical as well as biological studies. 
The formation of ion-pairs or ion-complexes in natural waters can have a major effect on the rates of redox processes, mineral solubility and biochemical availability [6]. Metals concentrations in aquatic ecosystems are usually monitored by measuring their concentrations in water, sediments and biota, which generally exist in low levels in water and attain considerable concentration in sediments and biota [7].

Most frequently metals are transported from land surface to water bodies. The consequence of metals disposed to the water can lead hazardous to man through his food. Dissolved constituents of water bodies are often determined as a major component for baseline limnological studies. The major ions $\mathrm{Ca}^{2+}, \mathrm{Mg}^{2+}, \mathrm{Na}^{+}, \mathrm{K}^{+}, \mathrm{Cl}^{-}, \mathrm{SO}_{4}{ }^{2-}, \mathrm{HCO}_{3}{ }^{-}$, and $\mathrm{CO}_{3}{ }^{2-}$ are essential constitute of water and responsible for ionic salinity as compared with other ions. The use of water in agriculture is growing, population growth and urbanization which all lead to the generation of more waste water in urban areas. The massive disposal of quantities of metal waste at landfills can lead to metal pollution of ground and surface water [8].

Due to the natural factors such as soil erosion, sediment loading, solution of minerals and increasing anthropogenic activities, the nature of the aquatic environment will change. This change in the aquatic environment will affect fish's habitat in the lake Chamo. Even though Lake Chamo attract attention of many researchers due to its historical and scientific importance currently, there was no document appeared regarding the accumulation or concentration of these essential and trace elements as well as the effect of seasonal variation on the lake water.

This study is designed to determine the current level of the concentrations of metals such as sodium $(\mathrm{Na})$, magnesium $(\mathrm{Mg})$, potassium $(\mathrm{K})$, calcium $(\mathrm{Ca})$, chromium $(\mathrm{Cr})$, cobalt $(\mathrm{Co})$, nickel $(\mathrm{Ni})$, manganese $(\mathrm{Mn})$ and copper $(\mathrm{Cu})$ in water. The status of the water parameters like temperature, dissolved oxygen, $\mathrm{pH}$, turbidity, conductivity, salinity and total dissolved solid of the lake water were also investigated in this study.

\subsection{Objectives of the Study}

\subsubsection{General Objective}

To evaluate seasonal variation in the composition of major and trace elements in the water.

\subsubsection{Specific Objectives}

1. To study the physicochemical parameters of the water.

2. To compare and contrast seasonal variation in the composition of major and trace elements in the water.

3. To correlate the water metal content with its physicochemical parameters.

\section{Materials and Methods}

\subsection{Study Area}

Lake Chamo is located in the Southern Nations Nationalities and Peoples Region (SNNPR) of southern Ethiopia. It is located in the Great Rift Valley at an elevation of 1,235 meters to the south of Lake Abaya and city of Arbaminch and east of the Guge Mountains. The lake's northern end lies in the Nechisar National Park. Earlier studies (Amha Belay and Wood, 1982) stated that Lake Chamo has a surface area of $551 \mathrm{~km}^{2}$ and a maximum depth of $16 \mathrm{~m}$. However, according to Seleshi Bekele (2006), the surface area of the lake declined to about $335 \mathrm{~km}^{2}$. Elizabeth Kebede (1996) reported a maximum depth of $13 \mathrm{~m}$. The lake is fringed with beds of typha as well as wetlands. The rivers draining in to Lake Chamo are listed as: Sile, Argoba, Wezeka, Sego, as well as overflow from Lake Abaya brought to it by the Kulfo River. Oscar Neumann explored the area in 1901 and found that a dry channel connecting Lake Chamo to the Sagan River which led him to conclude the lake contributes to the Sagan in years of heavy rainfall. [10].

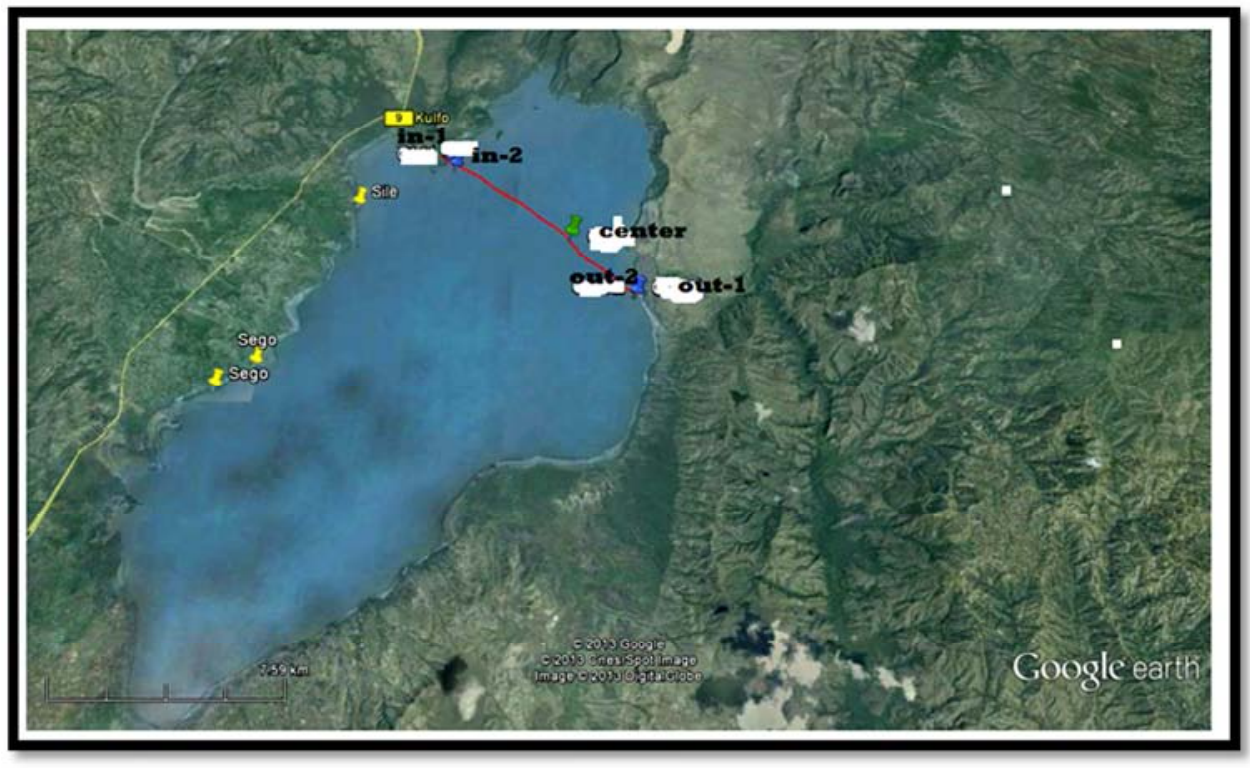

Figure 1. Map of Lake Chamo. 


\subsection{Experimental Procedures}

\subsubsection{Sample Collection}

Water sampling

The Water samples were collected seasonally (winter 2012/13 - spring 2013). One liter polyethylene bottles were used for collecting water samples. The bottles were cleaned with detergents and rinsed with deionized water. During the sampling period the bottles were rinsed with the lake water two times and then used for collecting the water samples. Water samples were collected from five sites which ranges from the entry of kulfo river to the out flow through Sagan and the GPS reading for each sites were, inlet-1(N5 ${ }^{\circ} 55.174^{\prime}$, $\left.\mathrm{E} 37^{\circ} 33.541^{\prime}\right)$, inlet-2(N5 ${ }^{\circ}$ 54.979', E37 33.762$)$, center (N5 $\left.{ }^{\circ} 52.801, \mathrm{E}^{\circ} 7^{\circ} 36.401\right)$, outlet-1(N5 51.360 , E3737.949) and outlet-2(N5 51.393 , E3737.903) as shown on figure 1. The collected samples were placed in icebox and brought to laboratory for farther analysis. While collecting the water samples, the physicochemical characteristics of the water like dissolved oxygen (DO), total dissolved solids (TDS), conductivity, $\mathrm{pH}$, salinity, temperature and turbidity also have been checked in situ along with GPS measurement.

\subsubsection{Sample Preparation}

Preparation of water sample

As the water which was collected from the lake contains many different suspended and dissolved materials that may affect the instrument's sample inlet line (AAS and Flame photometers) while measurements are taken, for this purpose the sample was treated taking it to Arbaminch University Chemistry Laboratory, the water sample was centrifuged for $15 \mathrm{~min}$ and about $500 \mathrm{~mL}$ of water was filtered through what-man filter paper. The filtrate was acidified with 1.00
$\mathrm{mL}$ conc. $\mathrm{HNO}_{3}$ and kept in the refrigerator at $4{ }^{\circ} \mathrm{C}$ until analysis.

\subsubsection{Sample Analysis}

Determination of major and trace metals

A series of working standard solutions of metals were prepared by appropriate dilution of the metal stock solutions with distilled, deionized water. After getting of the absorbance (from AAS and flame photometer) of each prepared sample, the calibration graph was constructed as absorbance versus concentration with the help of Origin lab 8.1 software, for each element using the prepared standard solutions. The metals $\mathrm{Mg}, \mathrm{Ca}, \mathrm{Cr}, \mathrm{Mn}, \mathrm{Fe}, \mathrm{Co}, \mathrm{Ni}, \mathrm{Cu}$ and $\mathrm{Zn}$ in the prepared samples of water were determined with the Buck Scientific 210VGP atomic absorption spectrophotometer while $\mathrm{Na}$ and $\mathrm{K}$ concentrations were determined by flame photometer (Model PFP7).

Determination of physicochemical parameters of the water

The physicochemical parameters of the water like dissolved oxygen (DO) was checked by (model 970) $\mathrm{DO}_{2}$ meter; conductivity, TDS, Turbidity and salinity were checked by using Conductivity meter-4200 and high quality 40 digital multi-meter (HQ40d) and $\mathrm{P}^{\mathrm{H}}$ of the water by $\mathrm{P}^{\mathrm{H}}$ Meter. All those parameters were measured in situ.

\subsection{Data Analysis}

The correlation of physicochemical parameters and the levels of metals in lake water were assessed using SPSS v16.0. Software like Origin lab. 8.1 and Microsoft office excel 2007 were used for graphs and figures presentation.

\section{Results}

Table 1. Physicochemical parameter measurements taken in both winter and spring season from Lake Chamo.

\begin{tabular}{|c|c|c|c|c|c|c|c|c|c|c|c|}
\hline \multirow[b]{2}{*}{ Parameters } & \multicolumn{6}{|c|}{ Water sample taken in winter } & \multicolumn{5}{|c|}{ Water sample taken in spring } \\
\hline & units & Inlet-1 & Inlet-2 & Center & Outlet-1 & Outlet-2 & Inlet-1 & Inlet-2 & Center & Outlet-1 & Outlet-2 \\
\hline $\mathrm{PH}$ & - & 9.45 & 9.45 & 9.39 & 9.43 & 9.44 & 9.30 & 9.33 & 9.38 & 9.33 & 9.40 \\
\hline TDS & $\mathrm{mg} / \mathrm{L}$ & 815 & 905 & 910 & 895 & 908 & 865 & 910 & 920 & 905 & 919 \\
\hline Conductivity & $\mu \mathrm{s} / \mathrm{cm}$ & 1746 & 1838 & 1893 & 1965 & 1926 & 1739 & 1835 & 1892 & 1960 & 1925 \\
\hline temperature & ${ }^{\circ} \mathrm{C}$ & 25.5 & 25.9 & 24.5 & 27 & 27.6 & 25.8 & 26.9 & 24.6 & 29 & 27 \\
\hline salinity & ppt & 0.87 & 0.92 & 0.82 & 0.93 & 0.92 & 0.87 & 0.82 & 0.81 & 0.84 & 0.82 \\
\hline turbidity & NTU & 28.02 & 26.20 & 21.59 & 23.54 & 22.78 & 36.02 & 37.21 & 22.59 & 26.54 & 23.78 \\
\hline
\end{tabular}

*** Water's physicochemical Parameters measured in five sampling sites on Lake Chamo

Table 2. Metals concentration in water samples taken in both winter and spring season from Lake Chamo.

\begin{tabular}{|c|c|c|c|c|c|c|c|c|c|c|}
\hline \multirow[b]{2}{*}{ Metals } & \multicolumn{5}{|c|}{ Water sample-1 } & \multicolumn{5}{|c|}{ water sample-2 } \\
\hline & Inlet-1 & Inlet-2 & Center & Outlet-1 & Outlet-2 & Inlet-1 & Inlet-2 & Center & Outlet-1 & Outlet-2 \\
\hline $\mathrm{Na}$ & 18 & 15.5 & 12.8 & 22 & 18.9 & 15.6 & 14.7 & 12 & 17.5 & 16 \\
\hline $\mathrm{Mg}$ & 0.97 & 0.84 & 0.34 & 0.86 & 0.79 & 0.51 & 0.62 & 0.33 & 0.47 & 0.38 \\
\hline $\mathrm{K}$ & 16 & 13 & 10 & 19 & 17 & 13 & 12 & 10 & 12 & 11 \\
\hline $\mathrm{Ca}$ & 3.9 & 2.5 & 1.6 & 5.5 & 3.0 & 3.0 & 3.9 & 1.5 & 2.5 & 1.5 \\
\hline $\mathrm{Cr}$ & 3.5 & 0.65 & 0.61 & 4.0 & 3.5 & 1.20 & 0.65 & 0.60 & 1.20 & 0.65 \\
\hline $\mathrm{Co}$ & 3.63 & 1.90 & 1.50 & 3.8 & 3.0 & 1.86 & 1.64 & 1.50 & 3.80 & 3.63 \\
\hline $\mathrm{Mn}$ & 1.51 & 1.10 & 1,01 & 1.26 & 1.98 & 1.09 & 1.03 & 1.01 & 1.2 & 1.9 \\
\hline $\mathrm{Ni}$ & 1.10 & 0.94 & 0.78 & 1.13 & 0.90 & 0.89 & 1.10 & 0.78 & 0.94 & 0.86 \\
\hline $\mathrm{Cu}$ & 0.82 & 0.66 & 0.53 & 1.20 & 0.71 & 0.78 & 0.68 & 0.50 & 0.71 & 0.66 \\
\hline
\end{tabular}

*** Concentration of metals in water sample 1 and 2 , all values are given in $\mathrm{mg} / \mathrm{L}$ 
Table 3. The mean values of metals concentration and physicochemical parameter of the water taken in winter season.

\begin{tabular}{llll}
\hline Metals & $\begin{array}{l}\text { Mean of metals } \\
\text { Concentration }\end{array}$ & $\begin{array}{l}\text { Physicochemical } \\
\text { parameters }\end{array}$ & $\begin{array}{l}\text { Mean of } \\
\text { Physicochemical values }\end{array}$ \\
\hline $\mathrm{Na}$ & 17.44 & $\mathrm{pH}$ & 9.43 \\
$\mathrm{Mg}$ & 0.76 & $\mathrm{TDS}$ & 886.6 \\
$\mathrm{~K}$ & 15 & Conductivity & 1874 \\
$\mathrm{Ca}$ & 3.3 & Temperature & 26.1 \\
$\mathrm{Cr}$ & 2.4 & Salinity & 0.89 \\
$\mathrm{Co}$ & 2.7 & Turbidity & 24.4 \\
$\mathrm{Ni}$ & 0.97 & DO & 7.44 \\
$\mathrm{Mn}$ & 1.4 & & \\
$\mathrm{Cu}$ & 0.78 & & \\
\hline
\end{tabular}

Table 4. The mean values of metals concentration and physicochemical parameter of the water taken during spring season.

\begin{tabular}{llll}
\hline Metals & $\begin{array}{l}\text { Mean of metals } \\
\text { Concentration }\end{array}$ & $\begin{array}{l}\text { Physicochemical } \\
\text { parameters }\end{array}$ & $\begin{array}{l}\text { Mean of } \\
\text { Physicochemical values }\end{array}$ \\
\hline $\mathrm{Na}$ & 13.2 & $\mathrm{pH}$ & 9.34 \\
$\mathrm{Mg}$ & 0.46 & TDS & 904 \\
$\mathrm{~K}$ & 11.6 & Conductivity & 1870 \\
$\mathrm{Ca}$ & 2.48 & Temperature & 26.7 \\
$\mathrm{Cr}$ & 0.86 & Salinity & 0.832 \\
$\mathrm{Co}$ & 2.5 & Turbidity & 29.23 \\
$\mathrm{Ni}$ & 0.91 & DO & 7.14 \\
$\mathrm{Mn}$ & 1.25 & & \\
$\mathrm{Cu}$ & 0.67 & & \\
\hline
\end{tabular}

Table 5. The correlation between mean metal concentration and physicochemical parameter of the water taken in the winter season.

\begin{tabular}{llll}
\hline Correlations - 1 & & phy.chem \\
& & $\begin{array}{l}\text { Water metal } \\
\text { values }\end{array}$ & $\begin{array}{l}\text { content } \\
\text { phy.chem }\end{array}$ \\
values & Pearson Correlation & 1 & 0.387 \\
& Sig. (2-tailed) & & 0.391 \\
Water metal & N & 7 & 7 \\
content & Pearson Correlation & 0.387 & 1 \\
& Sig. (2-tailed) & 0.391 & \\
\hline
\end{tabular}

Table 6. The correlation between mean metal concentration and physicochemical parameter of the water taken during the spring season.

\begin{tabular}{llll}
\hline Correlation - 2 & & phy.chem & $\begin{array}{l}\text { Water metal } \\
\text { content }\end{array}$ \\
\hline & & values & 0.393 \\
& & 1 & 0.383 \\
phy.chem & Pearson Correlation & & 7 \\
values & Sig. (2-tailed) & 7 & 1 \\
& $\mathrm{~N}$ & 0.393 & \\
Water metal & Pearson Correlation & 0.383 & 8 \\
content & Sig. (2-tailed) & 7 & \\
& $\mathrm{~N}$ & & \\
\hline
\end{tabular}

\section{Discussion}

\subsection{Physicochemical Parameters of the Water}

The water parameter measurements have indicated the variation of the quality of water within the two consecutive seasons. The physicochemical parameter reading taken from Lake Chamo within the two seasons is given in table 1. The reading obtained in winter season showed that, $\mathrm{P}^{\mathrm{H}}$ of the water ranges in $9.39-9.45$, total dissolved solids (TDS) 815 -
$910 \mathrm{mg} / \mathrm{L}$, conductivity $1746-1965 \mu \mathrm{S} / \mathrm{cm}$, temperature 25.5 $-27.6^{\circ} \mathrm{C}$, salinity $0.87-0.93 p p t$, turbidity $21.59-28.21 \mathrm{NTU}$ and dissolved oxygen (DO) falls in the ranges of $6.37-8.24$ $\mathrm{mg} / \mathrm{L}$. while the data obtained in the next season (spring) have some variation, $\mathrm{P}^{\mathrm{H}}$ ranges between $9.30-9.40$, total dissolved solids (TDS) $865 \mathrm{mg} / \mathrm{L}-920 \mathrm{mg} / \mathrm{L}$, conductivity $1739-1960 \mu \mathrm{S} / \mathrm{cm}$, temperature $25.8-29^{\circ} \mathrm{C}$, salinity $0.81-$ $0.87 \mathrm{ppt}$, turbidity $22.59-37.21 \mathrm{NTU}$ and dissolved oxygen (DO) in the ranges of $6.27-8.24 \mathrm{mg} / \mathrm{L}$. so these difference or variation in the physicochemical parameter measurements of the water of lake Chamo is expected to be the result of seasonal changes.

\subsection{1. pH (Acidity or Alkalinity)}

The water $\mathrm{pH}$ value is determined by the relative concentrations of $\mathrm{H}^{+}$ion and $\mathrm{OH}^{-}$ion. Water with a $\mathrm{pH}$ of 7 has equal concentrations of $\mathrm{H}^{+}$ion and $\mathrm{OH}^{-}$ion and is considered to be a neutral solution. If a solution is acidic $(\mathrm{pH}$ $<7$ ), the concentration of $\mathrm{H}^{+}$ion is greater than the concentration of $\mathrm{OH}^{-}$ion. If a solution is basic $(\mathrm{pH}>7)$, the concentration of $\mathrm{H}^{+}$ion is less than the concentration of $\mathrm{OH}^{-}$ ion. In this study, the $\mathrm{pH}$ value of the lake water is found to be slightly alkaline with the range of $9.43-9.45$ and $9.30-$ 9.43 in dry and wet seasons, respectively. The mean $\mathrm{pH}$ values between both seasons showed no significant difference. The $\mathrm{pH}$ values measured in both seasons were found above the upper limit defined by WHO guide lines 6.58.5 [11]. The $\mathrm{pH}$ was found to have slight variations between stations and seasons. Higher $\mathrm{pH}$ may result due to waste discharge, microbial decomposition of organic matter in the water body or may be attributed to sewage discharge by surrounding human population Patil, S. G et al [12]. Rainfall generally has a $\mathrm{pH}$ value of 5 to 6.5 which is acidic as a result of dissolved carbon dioxide and air pollutants such as sulphur dioxide or nitrogen oxides. If rainwater flows over soil containing hard water minerals, its $\mathrm{pH}$ usually increases. Bicarbonate ions, $\mathrm{HCO}_{3}^{-}$, resulting from limestone deposits react with water to produce $\mathrm{OH}^{-}$ions according to the reaction given:

$$
\mathrm{HCO}_{3}^{-}+\mathrm{H}_{2} \mathrm{O}-\mathrm{H}_{2} \mathrm{CO}_{3}^{-}+\mathrm{OH}^{-}
$$

This results in lakes often being basic with $\mathrm{pH}$ values between 7 and 8 , sometimes as high as 8.5. The measure of $\mathrm{pH}$ is very important indication of the quality of water due to the sensitivity of organisms to the $\mathrm{pH}$ of their environment. Small changes in $\mathrm{pH}$ can affect the existence of biological life and most of them thrive in a quite narrow and critical $\mathrm{pH}$ range. The table below shows $\mathrm{pH}$ effect on aquatic life.

\subsubsection{Temperature, Total Dissolved Solids (TDS) and Conductivity}

Temperature is one of the important factors in aquatic environment since it regulates the physicochemical as well as the biological activities. According to the present study, the wet season temperature is higher than the dry season and it ranges from $25.5^{\circ} \mathrm{C}-27.6^{\circ} \mathrm{C}$ and $25.8^{\circ} \mathrm{C}-29^{\circ} \mathrm{C}$ in the winter 
and spring, respectively which is similar to previous studies, Yosef T. G and Eyasu shumbolo [13, 14]. In both seasons, the least temperature was recorded at the center of the lake which has maximum depth. Shade is important to the health of the water body as it reduces the warming effect of direct sunlight. The study showed as the temperature of the lake slightly exceeds the permissible limit $24^{\circ} \mathrm{C}-28^{\circ} \mathrm{C}$ [15]. Some human activities removed shade trees from the area, allowing more sunlight to reach the water, causing temperature to rise. Temperature of air above the water body may affect water temperature depending on the depth of the water. Shallow water bodies are more susceptible to temperature changes than deep water. The increment in the lake water temperature will affect solubility of dissolved oxygen. More gas can be dissolved in cold water than warm; therefore animals requiring a high level of dissolved oxygen will only thrive in cold water. Increased water temperature can cause an increase in the photosynthetic rate of aquatic plants and algae, which can lead to increased plant growth and algal blooms, and harm the local ecosystems, Metabolic rate of organisms and Resistance in organisms if water becomes too hot or too cold, organisms become stressed, lowering their resistance to pollutants, diseases and parasites.

Solids are found in streams in two forms, suspended and dissolved form. Dissolved solids in freshwater samples include soluble salts that yield ions such as sodium $\left(\mathrm{Na}^{+}\right)$, calcium $\left(\mathrm{Ca}^{2+}\right)$, magnesium $\left(\mathrm{Mg}^{2+}\right)$, bicarbonate $\left(\mathrm{HCO}^{3-}\right)$, sulfate $\left(\mathrm{SO}^{2-}\right)$, or chloride $\left(\mathrm{Cl}^{-}\right)$. The TDS concentration in a body of water is affected by many different factors. A high concentration of dissolved ions is not, by itself, an indication that a stream is polluted or unhealthy. It is normal for water bodies to dissolve and accumulate fairly high concentrations of ions from the minerals in the rocks and soils over which they flow. The present study found the TDS value in ranges from 815 to $910 \mathrm{mg} / \mathrm{L}$ and 865 to $920 \mathrm{mg} / \mathrm{L}$ in the winter and spring season respectively. Among the sampling stations, the maximum reading was obtained for site centre with values $910 \mathrm{mg} / \mathrm{L}$ in winter and $920 \mathrm{mg} / \mathrm{L}$ in spring season. This result exceeds the WHO permissible limit of $500 \mathrm{mg} / \mathrm{L}$ WHO, 1993[16]. High levels of TDS in water used for drinking purposes may lead to many diseases, Sabata, B. C and Nayar, M. P [17]. As deposits contain salts $(\mathrm{NaCl}$ and $\mathrm{KCl})$ or limestone $\left(\mathrm{CaCO}_{3}^{-}\right)$, significant concentrations of $\mathrm{Na}^{+}, \mathrm{K}^{+}$, $\mathrm{Cl}^{-}$will result, as well as hard-water ions, such as $\mathrm{Ca}^{2+}$ and $\mathrm{HCO}_{3}{ }^{-}$from limestone. TDS is sometimes used as a "watchdog" environmental test and its values will change when ions are introduced to water from salts, acids, bases, hard-water minerals, or soluble gases that ionize in solution. There are many possible man made sources of ions that may contribute to elevated TDS readings. Fertilizers from fields can add a variety of ions to a stream. Increases in TDS can also result from runoff from roads that have been salted in the winter. TDS values in lakes and streams are typically found to be in the range of 50 to $250 \mathrm{mg} / \mathrm{L}$ but in areas of especially hard water or high salinity, TDS values may be $500 \mathrm{mg} / \mathrm{L}$ or higher, U.S EPA [15].

Conductivity is a measure of water's capability to carry an electric current and also it is a tool to assess the purity of water. Minerals and salts must be dissolved in water in order for it to conduct electricity; as the concentration of dissolved solids increases, so does the conductivity of the liquid. The present investigation found the conductivity of Lake Chamo water in the range of $1746-1965 \mu \mathrm{S} / \mathrm{cm}$ and $1739-1960$ $\mu \mathrm{S} / \mathrm{cm}$ in the dry and wet season, respectively. The value is similar to that obtained by eyasu shumbolo et al [14] but much higher than the value reported by earlier work, Ababu teklemariam [2]. The current high conductivity of the lake is also attributable to increased ionic concentration due to evaporative water lose. The wide variations in the conductivity values between seasons could be attributed to the combined influence of sea water intrusion with the flooding tide and influence of fresh water particularly during the rainy season. Among the sites, maximum conductivity reading was recorded for outlet-1 both in the winter and spring which was 1965 and $1960 \mu \mathrm{S} / \mathrm{cm}$, respectively. The variation between the stations is suggestive for the influence on the lake while the seasonal differences observed for the conductivity which is a clear indication of the role of season in the ionic distribution in the lake. Dissolved solids may originate from a variety of organic and inorganic sources that can be either natural or human derived, such as the degradation of rock or plant matter or agricultural runoff of topsoil. The electrical conductivity measured in Lake Chamo exceeded the values of $1000 \mu \mathrm{S} / \mathrm{cm}$ maximum for fresh water bodies [18]. The high electrical conductivity values in both seasons indicate the presence of high concentrations of total dissolved solid from non-point sources such as municipal effluents.

\subsubsection{Salinity, Turbidity and Dissolved Oxygen}

Salinity is a measure of the total salt concentration, comprising mostly of $\mathrm{Na}^{+}$and $\mathrm{Cl}^{-}$ions as well as small quantities of other ions like $\mathrm{Mg}^{2+}, \mathrm{K}^{+}$, or $\mathrm{SO}_{4}{ }^{2-}$. It is the total of all non-carbonate salts dissolved in water. In the present study salinity of the lake Chamo ranges from $0.87-0.93 \mathrm{ppt}$ and $0.81-0.87 \mathrm{ppt}$ in the winter and spring season, respectively. Among the stations the maximum salt concentration is recorded at inlet- 2 , outlet- 1 and outlet- 2 in the dry season and at inlet- 1 in the wet season. Increment in salinity has also been reported by Elzabeth kebede of Chamo in the last four decades [19]. Demeke admasu [20] also reported a salinity level of $1 \mathrm{~g} / \mathrm{L}$ as compared to $0.6 \mathrm{~g} / \mathrm{L}$ of salinity that was measured by Loffredo and Maldura [21]. It is evident that the water has become more concentrated, which might be attributed to high evaporation. The major ions $\mathrm{Ca}^{2+}, \mathrm{Mg}^{2+}, \mathrm{Na}^{+}, \mathrm{K}^{+}, \mathrm{Cl}^{-}, \mathrm{SO}_{4}{ }^{2-}, \mathrm{HCO}^{3-}$ and $\mathrm{CO}_{3}{ }^{2-}$ are essential constituent of water and responsible for ionic salinity as compared with other ions [22].

Turbidity is a measure of the water's lack of clarity and water with high turbidity is cloudy, while water with low turbidity is clear. The more particles in the water, the more light is reflected off the particles and therefore the higher the turbidity or cloudiness. The present investigation found the turbidity of the lake in the ranges of $21.59-28.02 \mathrm{NTU}$ in the 
winter season and $22.59-37.21 \mathrm{NTU}$ in the spring. The result inferred that Lake Chamo is more turbid in spring season than winter time. Comparatively inlet-1 and inlet-2 showed higher reading in both seasons. The result exceeds the permissible limit of 10 NTU set by BIS 1991 [23]. The turbidity of the lake may increased as a result of Soil erosion, silt and clay deposition, Urban runoff, Industrial waste, sewage treatment effluent; particulates, abundant bottomdwelling organisms and Organic matter, microorganisms; decaying plants and animals; petrol, diesel or oil from roads. High turbidity decreases the amount of sunlight able to penetrate the water, thereby decreasing the rate of photosynthesis. Reduced clarity also makes the water less aesthetically pleasing, making it less desirable for many water uses. When water is cloudy, sunlight will warm it more efficiently because suspended particles absorb the sunlight, warming the water. This can lead to problems associated with increased water temperature.

Oxygen $\left(\mathrm{O}_{2}\right)$ is undoubtedly the most important of the gases, since most aquatic organisms need it to survive. The dissolved oxygen (DO) concentration of lake Chamo water ranged from $6.37 \mathrm{mg} / \mathrm{L}-8.24 \mathrm{mg} / \mathrm{L}$ and $6.27 \mathrm{mg} / \mathrm{L}-8.24 \mathrm{mg} / \mathrm{L}$ in winter and spring season, respectively. The maximum reading is recorded at the center of the lake with a value of $8.24 \mathrm{mg} / \mathrm{L}$ in both seasons. Permissible limit of DO is $5 \mathrm{mg} / \mathrm{L}$ and higher DO values often more than the saturation values were found mostly in the station where more weeds are present and may be due to their photosynthetic activities [24]. Normally high DO was encountered in unpolluted areas while at polluted areas level of DO is very less. Low content of DO assign of organic pollution, it also due to inorganic reluctants like Hydrogen sulfite, Ammonia, Nitrate, ferrous ion and other such oxidisable substances[25]. Farther depletion of DO to the level of anaerobic is the most critical manifestation of pollution. DO was an indicator for organic pollution [26].

\subsection{Metal Concentrations in Water}

Metals concentration in the water samples taken from Lake Chamo in two seasons from winter 2012/13 to spring 2013, have some variation as there is different water bodies or rivers that drain in to the lake during rainy season. During spring season most rivers that flow in to Lake Chamo will get higher amount of water content as a result of rainfall. This water will carry both organic and inorganic substances that are available in the surrounding. Due to the addition of those substances to the lake, the water characteristics and concentration of essential and trace elements present in the lake will be altered and also the physicochemical properties of the water also has been increased as a consequence of those impurities introduce in to the lake. The values of the concentration of metals in water in the same season vary strongly among the sampling sites. The metal concentrations of the water at five different sampling sites which was calculated from the absorbance given in appendix 3 and 4 are given in table 2. According to this study, the concentration of $\mathrm{Na}$ ranges between 18 - 22, Mg 0.34-0.97, K 10-19, Ca 1.6 -
5.5, Cr 0.61- 4.0, Co 1.50-3.8, Ni 0.78-1.10, Mn 1.01- 1.98 and $\mathrm{Cu} 0.53-1.20 \mathrm{mg} / \mathrm{L}$ in the winter season. But during rainy season of the area ( spring), the concentrations of those metals has been changed, $\mathrm{Na}$ ranges in $12-17.5, \mathrm{Mg} 0.51$ 0.62, K 10- 13, Ca 1.5- 3.9, Cr 0.60- 1.20, Co 1.50- 3.80, Ni 0.78-1.10, $\mathrm{Mn} 1.01-1.9$ and $\mathrm{Cu} 0.50-0.78 \mathrm{mg} / \mathrm{L}$.

The concentration of essential and trace metals in lakes can be varied from season to season which may be due to the tributaries or rivers that drain in to the lake, anthropogenic activities such as industry, agriculture, overgrazing and burning of fossil or the events taking place naturally like volcanic eruption, flood, soil erosion, sediment loading and solution of minerals. As it was explained Lake Chamo has some rivers that drain in to it. Among those sile and kulfo rivers are the main, especially Kulfo River which drains near to the Arbaminch town could have higher water volume as a result of municipal wastes and effluents released to it. The physical, chemical and biological processes occurring permanently in an aquatic environment should be considered to explain the inorganic elements concentration. Dissolved metal ions create turbidity, discoloration of lake water, can precipitate and form bottom sludge. Limits on individual metals are usually based on toxicity levels. Various metals including those which are essential micronutrients are toxic to organisms at their higher concentrations. Normally the free form of the element is potentially toxic to aquatic biota. Complexation with organic ligands significantly reduces their concentration and the adverse effects. Other factors such as $\mathrm{pH}$, salinity and hardness also affect the concentration of free metal ions and thus regulate toxicity. However, several regulatory agencies have specified limits on total metals to provide a sufficient safeguard against possible synergistic effects. This study showed the variation in metal concentration of the water of Lake Chamo from five different sampling sites (inlet-1, inlet-2, center, outlet-1 and outlet-2) within two consecutive seasons' winter and spring.

\subsubsection{Sodium, Potassium, Magnesium and Calcium}

In the present study the concentration of $\mathrm{Na}$ ranges from 18 to $22 \mathrm{mg} / \mathrm{L}$ in winter while in the spring it falls in the ranges of $12-17.5 \mathrm{mg} / \mathrm{L}$ as it is revealed from the result Table 2. The concentration of $\mathrm{Na}$ is increased in winter as the water level of the lake decrease and it is decreased in spring when water size of the lake was increased. Among the sampling sites, the maximum $\mathrm{Na}$ concentration is identified in site outlet-1 which has values $22 \mathrm{mg} / \mathrm{L}$ and $17.5 \mathrm{mg} / \mathrm{L}$ in winter and spring, respectively. The value obtained from this study lower than the permissible limit of $\mathrm{Na} 60-120 \mathrm{mg} / \mathrm{L}$ BIS, 1998 [27] and also so lower than reported by Mohamed, H. et al on lake Qarun of Egypt (8.72 g/L) [9]. The higher concentration of sodium limits the biological diversity due to osmotic stress.

Potassium plays the same role in water as sodium and occurs in small amounts but is regarded as an important macronutrient in the metabolism of aquatic ecosystems. In this study the concentration of potassium is in the ranges of $10-19 \mathrm{mg} / \mathrm{L}$ and $10-13 \mathrm{mg} / \mathrm{L}$ in winter and spring, 
respectively. The concentration of $\mathrm{K}$ is decreased in the spring due to increase in volume of the lake water. Among the sampling sites, outlet-1 sampling site showed maximum potassium concentration of $19 \mathrm{mg} / \mathrm{L}$ in the winter while in the spring season, the maximum potassium concentration was observed in the inlet-1, $13 \mathrm{mg} / \mathrm{L}$. This is due to the high water inflow to the lake. The obtained values are greatly lower than reported by Mohamed, H. et al on lake Qarun of Egypt (398mg/L) [9].

Magnesium occurs in all natural waters. It is an essential constituent of chlorophyll. In this study, the concentration of magnesium has shown some variation within the two consecutive seasons. Magnesium acts as a limiting factor for the growth of phytoplankton. The concentration of $\mathrm{Mg}$ is in the ranges of $0.34-0.97 \mathrm{mg} / \mathrm{L}$ in the winter (table 3 ). In the spring season, the concentration falls in the ranges of $0.33-$ $0.62 \mathrm{mg} / \mathrm{L}$. The concentration of magnesium was higher in the winter than spring. Maximum $\mathrm{Mg}$ concentration was recorded in the sampling site of inlet-1 during winter and inlet-2 in spring. The presence of high magnesium concentration in water reduces its quality for domestic use. In the present investigation, the average magnesium concentration $(0.76 \mathrm{mg} / \mathrm{L})$ of Lake Chamo water is lower than the standard magnesium concentration $(30 \mathrm{mg} / \mathrm{L})$ in lake water, BIS 1998 [27].

The concentration of calcium in water depends on the residence time of the water in calcium rich geological formations. In this investigation the concentration of calcium is seen in the range of $1.6-5.5 \mathrm{mg} / \mathrm{L}$ and 1.5 to $3.9 \mathrm{mg} / \mathrm{L}$ in the winter and spring, respectively. The result depicted that the maximum concentration is obtained in the winter (5.5 $\mathrm{mg} / \mathrm{L}$ ) than the spring season. From all the sampling sites, the maximum concentration is recorded for outlet- 1 in the winter while in the spring, maximum calcium concentration is observed for inlet-2. The result of this study falls in the permissible range of $1.0-75 \mathrm{mg} / \mathrm{L}$, BIS 1998 [27]. But the obtained value is greatly lower than reported by Mohamed, H. et al on lake Qarun of Egypt (641 mg/L) [9].

Figure 2 and 3 shows the concentration of $\mathrm{Na}, \mathrm{Mg}, \mathrm{K}$ and $\mathrm{Ca}$ in the five sampling sites of water from Lake Chamo within the two consecutive seasons.

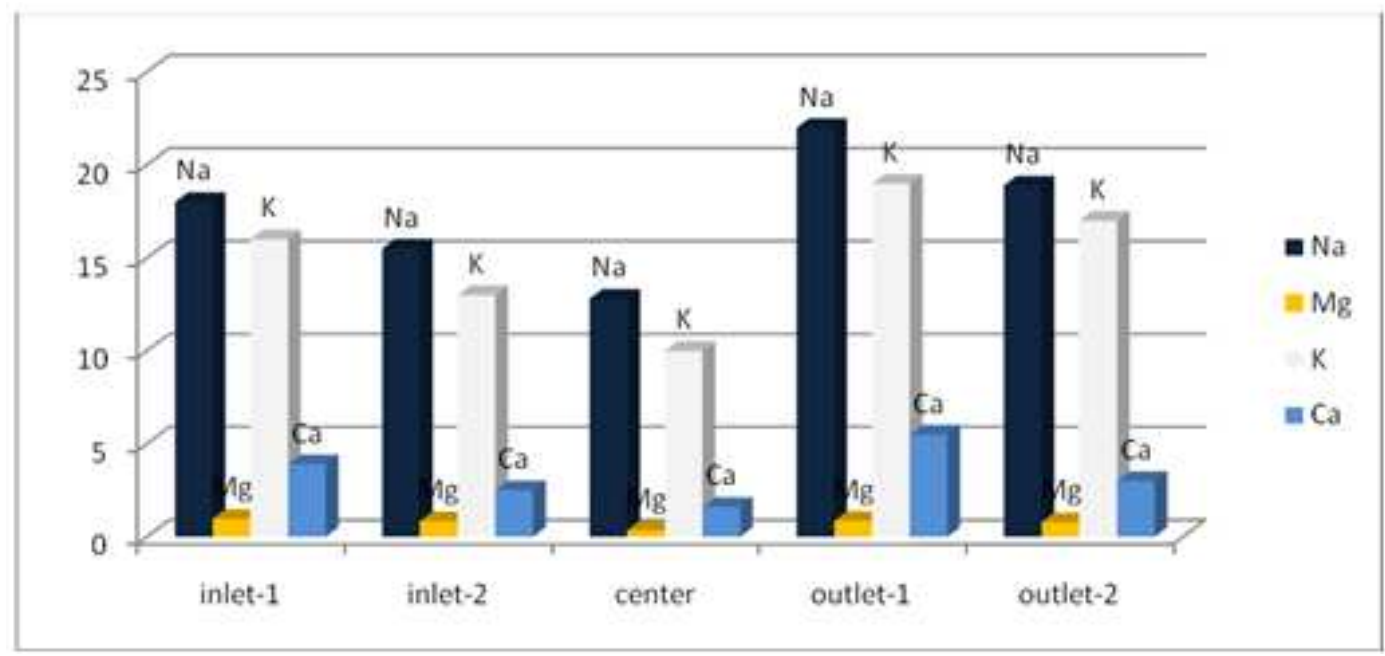

Figure 2. The concentratiaon of $\mathrm{Na}, \mathrm{Mg}, \mathrm{K}$ and $\mathrm{Ca}$ in the five sampling sites on Lake Chamo water during winter season.

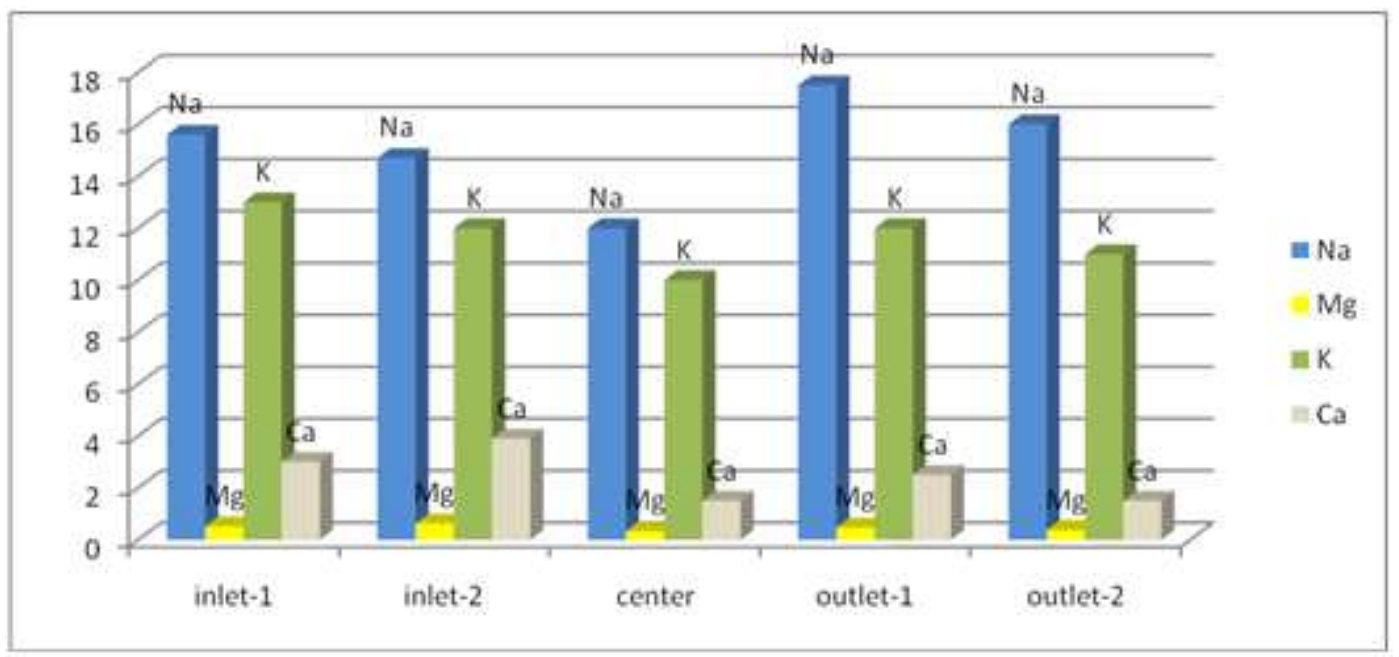

Figure 3. The concentratiaon of $\mathrm{Na}, \mathrm{Mg}, \mathrm{K}$ and $\mathrm{Ca}$ in the five sampling sites on Lake Chamo water during spring season. 
Figure 2 and 3 revealed that the concentration of the metals $\mathrm{Na}, \mathrm{K}, \mathrm{Mg}$ and $\mathrm{Ca}$ is higher in the outlet part of the lake in winter season while in spring, the concentration of the metal except $\mathrm{Na}$ is higher in the inlet part of the lake indicating as rain water brings those metals to the lake from the surrounding in the form of flood.

\subsubsection{Chromium, Cobalt and Nickel}

According to the result obtained from this study, the chromium concentration is in the ranges of $0.61-4.0 \mathrm{mg} / \mathrm{L}$ in the winter season. But in the spring, it falls in the range of $0.60-1.20 \mathrm{mg} / \mathrm{L}$. The concentration of chromium in winter is seen higher $(4.0 \mathrm{mg} / \mathrm{L})$ in outlet-1 while similar concentration is recorded for sampling sites, inlet-1 and outlet-2 (3.5 mg/L). In the spring season, the higher $\mathrm{Cr}$ level is calculated for inlet-1 and outlet-1 with a value of $1.20 \mathrm{mg} / \mathrm{L}$. This value is higher than reported by Kebede N. et al on lake Awasa and Ziway $(0.20$ and $0.129 \mathrm{mg} / \mathrm{L})$ and exceeds the permissible limit of WHO, Trivedi and Gurdeep $(0.05 \mathrm{mg} / \mathrm{L})$ of lake water $[29,30]$.

Cobalt is an essential constituent as a component of vitamin $\mathrm{B}_{12}$. In the present study the concentration of cobalt (given in Table 2) is in the ranges of $1.50 \mathrm{mg} / \mathrm{L}-3.80 \mathrm{mg} / \mathrm{L}$ in both seasons. The overall cobalt concentration of the lake was unchanged but there were some slight changes in concentration among the sampling sites. According to the result, the maximum cobalt concentration is recorded for outlet-1. The result revealed that the concentration of Co in all the sampling sites are almost constant that confirmed there is no external factors that affect the concentration of $\mathrm{Co}$ in Lake Chamo. But the result exceeds the permissible limit $(0.003 \mathrm{mg} / \mathrm{L})$ as WHO set for cobalt.

Nickel is known to be essential nutrient for microorganisms and aquatic life. The result of this study found the concentration of $\mathrm{Ni}$ in the range $0.78-1.10 \mathrm{mg} / \mathrm{L}$ in both winter and spring season. The higher concentration was calculated for inlet- 1 and inlet- 2 in the winter while in the spring the maximum concentration is recorded in inlet-2. The value obtained from this study slightly higher than reported by Öztürk, M. et al [12] on Avsard Dam lake in Turkey $(0.0004$ to $0.012 \mathrm{mg} / \mathrm{L})$ and also exceeds the permissible limit of WHO $(0.02 \mathrm{mg} / \mathrm{L})$ [29].

\subsubsection{Manganese and Copper}

The result presented in Table 3 revealed the concentration of manganese is higher in the winter season ranges from 1.01 to $1.98 \mathrm{mg} / \mathrm{L}$ than spring and it falls between 1.01 and 1.90 $\mathrm{mg} / \mathrm{L}$. The concentration variation of manganese in Lake Chamo within the two consecutive seasons is insignificant. Out of the sampling sites, the maximum concentration is recorded for outlet- 2 in both seasons which was 1.98 and $1.90 \mathrm{mg} / \mathrm{L}$, respectively. This is higher than reported by samir et $a l$ in the northern delta lakes, Egypt $(0.244 \mathrm{mg} / \mathrm{L})$ and is also exceeds the permissible limit $(0.05 \mathrm{mg} / \mathrm{L})$ of EPA and WHO [28, 29].

Copper is among the heavy metals which are available in fresh water. The source of these heavy metals in fresh water bodies is mainly through industrial effluent and municipal wastes released to water bodies. In the present study, the concentration of $\mathrm{Cu}$ is higher in the spring that ranges from $0.53 \mathrm{mg} / \mathrm{L}$ to $1.20 \mathrm{mg} / \mathrm{L}$ and it falls in the range of $0.50 \mathrm{mg} / \mathrm{L}$ - $0.78 \mathrm{mg} / \mathrm{L}$ in the spring (table 3 ). The outlet- 1 of the sampling site is recorded the maximum $\mathrm{Cu}$ concentration $(1.20 \mathrm{mg} / \mathrm{L})$ in the winter time and higher $\mathrm{Cu}$ concentration in the spring time is observed for inlet-1 $(0.78 \mathrm{mg} / \mathrm{L})$. The overall $\mathrm{Cu}$ level is higher in the winter time when the water volume decreased. The higher concentration in the station outlet-1 in winter time indicates the movement of the $\mathrm{Cu}$ toward the outlet when the volume of the water is higher. This result is higher than reported by samir et al $(0.186 \mathrm{mg} / \mathrm{L})$ but lower than the WHO permissible limit of $2.0 \mathrm{mg} / \mathrm{L} \mathrm{[29].}$

Figure 4 and 5 shows the concentration of $\mathrm{Cr}, \mathrm{Co}, \mathrm{Mn}, \mathrm{Ni}$ and $\mathrm{Cu}$ in the five sampling sites of water from Lake Chamo within the two consecutive seasons (winter and spring).

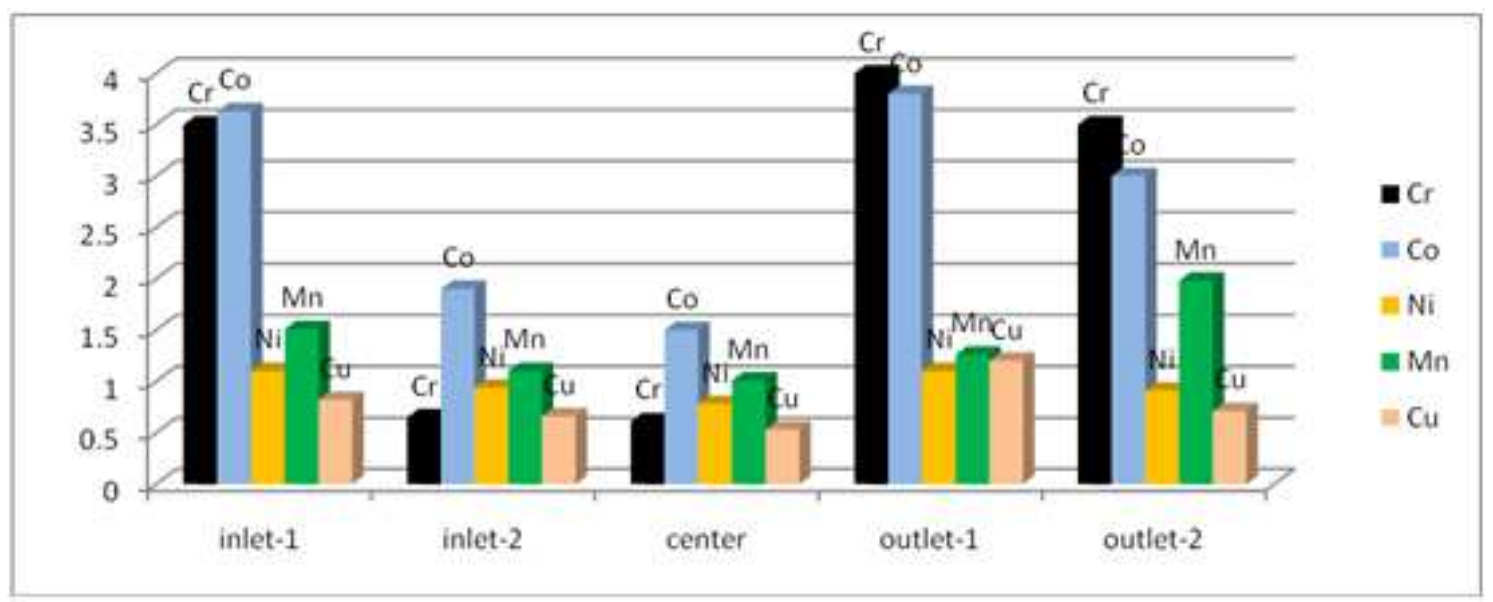

Figure 4. The concentration of $\mathrm{Cr}, \mathrm{Co}, \mathrm{Ni}, \mathrm{Mn}$, and $\mathrm{Cu}$ in five sampling sites on Lake Chamo water during winter season. 


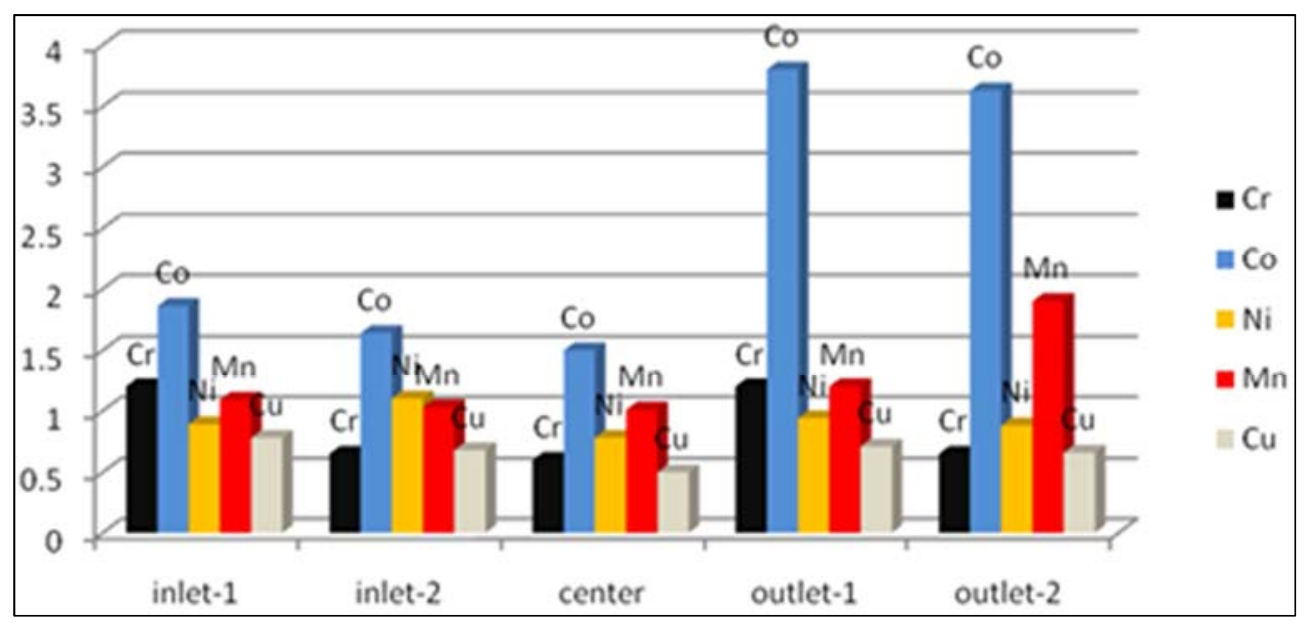

Figure 5. The concentration of $\mathrm{Cr}, \mathrm{Co}, \mathrm{Ni}, \mathrm{Mn}$, and $\mathrm{Cu}$ in five sampling sites on Lake Chamo water during spring season.

Figure 4 and 5 revealed that the concentration of the metals $\mathrm{Cr}, \mathrm{Co}, \mathrm{Ni}, \mathrm{Mn}$ and $\mathrm{Cu}$ is higher in the outlet part of the lake both in the winter and spring season. This indicates that there is no significant amount of those metal inter to the lake from the surrounding during rainy season.

\subsection{Correlation Between Metal Concentration of the Water and Physicochemical Parameters}

\subsubsection{Correlation Between Metal Concentration and Physicochemical Parameter of Water Sample Taken in the Winter Season}

According to the result given in table 5, the correlation between the mean metal concentration and physicochemical parameters of the water taken in the winter season showed a positive correlation with value of 0.387 . The increase in the metal concentration has direct relation with the increase in the physicochemical parameter.

\subsubsection{Correlation Between Metal Concentration and Physicochemical Parameter of Water Sample Taken in the Spring Season}

The result given in table 6 , showed the correlation between the mean metal concentration and mean physicochemical parameter values of water taken in the spring season. The physicochemical parameter values have been increased as the concentration of metals increased which implies the linear relationship of the two values.

\section{Conclusions}

This study revealed that the physicochemical variables such as temperature, $\mathrm{pH}$, TDS and DO of lake Chamo were slightly above the recommended limit of WHO. The values obtained for TDS, temperature and turbidity of water were higher in the wet (spring) season than dry (winter) season. The $\mathrm{pH}$ of this study showed lake Chamo water is alkaline which might have an effect on the bioavailability of dissolved metals. The turbidity of Lake Chamo is higher than the permissible limit of 10 NTU. Center of the lake showed higher value of DO in both season indicating that the higher the depth the higher would be DO value.

The physicochemical variables have also shown slight variation among the five different sampling sites. Salinity, EC and temperature showed higher values in sampling sites of outlet- 1 and outlet- 2 in the dry season while in the wet season, EC and temperature revealed higher values in sites of outlet- 1 and outlet-2. Salinity is higher in sites outlet- 1 and inlet-1. The turbidity of the water is higher in sites inlet-1 and inlet- 2 in both seasons and $\mathrm{pH}$ reading is higher in sites inlet1 and inlet- 2 in dry season but in the spring season, the higher $\mathrm{pH}$ reading is observed for outlet- 2 and center. Both TDS and DO showed higher value for sampling sites center and outlet-2 in both winter and spring season. Generally the physicochemical variables obtained from this study indicated that Lake Chamo has slightly shown variation in different season and this might affect the aquatic organism.

The level of dissolved major and trace elements like $\mathrm{Na}, \mathrm{K}$ and $\mathrm{Ca}$ were in the same range with the permissible limit of WHO while the concentration of $\mathrm{Cr}, \mathrm{Co}, \mathrm{Ni}, \mathrm{Mn}$ and $\mathrm{Cu}$ were slightly higher than the recommended limit. The value of $\mathrm{Mg}$ is below the permissible limit of lake water. The metal concentration has shown some variation within the two consecutive seasons. The metal concentration of the lake Chamo water was higher in the winter (dry) season where the level of the water was lower than spring (wet) season in which high rain fall exist.

The metal content of water of Lake Chamo among the five sampling sites has showed slight variation. The higher $\mathrm{Na}, \mathrm{K}$, $\mathrm{Ca}$ and $\mathrm{Mg}$ level was calculated for the sampling site of outlet-1 in the winter season while in the spring, inlet-2 showed higher $\mathrm{K}, \mathrm{Ca}$ and $\mathrm{Mg}$ level. The accumulation level of $\mathrm{Cr}, \mathrm{Co}$, $\mathrm{Ni}$ and $\mathrm{Cu}$ was higher in the sampling site of outlet-1 in the dry season while in the wet season, $\mathrm{Co}$ and $\mathrm{Cr}$ got higher at the same site (outlet-1), $\mathrm{Ni}$ at inlet-2 and $\mathrm{Cu}$ at inlet-1. The Mn level was higher at site of outlet-2 in both seasons. 


\section{Appendix}

Appendix 1. Absorbance of the Standard Solutions Prepared for Metal Determination in Water Samples.

\begin{tabular}{lll}
\hline Metals & concentration of standards & absorbance \\
\hline \multirow{3}{*}{$\mathrm{Na}$} & 10 & 0.017 \\
& 20 & 0.028 \\
& 40 & 0.046 \\
& 60 & 0.061 \\
$\mathrm{Mg}$ & 1 & 0.518 \\
& 3 & 0.661 \\
& 5 & 0.782 \\
& 7 & 0.892 \\
$\mathrm{~K}$ & 9 & 0.988 \\
& 10 & 0.013 \\
& 20 & 0.024 \\
& 40 & 0.043 \\
$\mathrm{Ca}$ & 60 & 0.059 \\
& 1 & 0.005 \\
& 3 & 0.009 \\
& 5 & 0.013 \\
$\mathrm{Cr}$ & 7 & 0.017 \\
& 9 & 0.019 \\
& 1 & 0.005 \\
& 3 & 0.006 \\
& 5 & 0.007 \\
& 7 & 0.008 \\
\hline
\end{tabular}

Absorbance of the prepared standard solutions

\begin{tabular}{lll}
\hline Metals & concentration of standards & absorbance \\
\hline \multirow{3}{*}{$\mathrm{Co}$} & 1 & 0.010 \\
& 3 & 0.017 \\
& 5 & 0.026 \\
& 7 & 0.036 \\
& 9 & 0.044 \\
$\mathrm{Ni}$ & 1 & 0.010 \\
& 3 & 0.019 \\
& 5 & 0.026 \\
& 7 & 0.034 \\
$\mathrm{Mn}$ & 9 & 0.041 \\
& 1 & 0.044 \\
& 3 & 0.087 \\
& 5 & 0.125 \\
$\mathrm{Cu}$ & 7 & 0.180 \\
& 9 & 0.222 \\
& 1 & 0.018 \\
& 3 & 0.038 \\
& 5 & 0.061 \\
& 7 & 0.082 \\
& 9 & 0.098 \\
\hline
\end{tabular}

**** Concentrations are in ppm

Appendix 2. Absorbance for Water Sample-1.

\begin{tabular}{llllll}
\hline Metals & \multicolumn{2}{l}{ Absorbance } & & & \\
\hline & Inlet-1 & inlet-2 & center & outlet-1 & outlet-2 \\
\hline $\mathrm{Na}$ & 0.028 & 0.026 & 0.020 & 0.031 & 0.029 \\
$\mathrm{Mg}$ & 0.57 & 0.52 & 0.50 & 0.54 & 0.53 \\
$\mathrm{~K}$ & 0.019 & 0.015 & 0.013 & 0.022 & 0.020 \\
$\mathrm{Ca}$ & 0.010 & 0.008 & 0.006 & 0.014 & 0.009 \\
$\mathrm{Cr}$ & 0.006 & 0.0053 & 0.0051 & 0.0063 & 0.006 \\
$\mathrm{Co}$ & 0.015 & 0.012 & 0.010 & 0.0159 & 0.0155 \\
$\mathrm{Ni}$ & 0.012 & 0.011 & 0.0101 & 0.014 & 0.010 \\
$\mathrm{Mn}$ & 0.050 & 0.046 & 0.044 & 0.049 & 0.053 \\
$\mathrm{Cu}$ & 0.013 & 0.011 & 0.010 & 0.020 & 0.012 \\
\hline
\end{tabular}

Appendix 3. Absorbance for Water Sample-2.

\begin{tabular}{|c|c|c|c|c|c|}
\hline \multirow[t]{2}{*}{ Metals } & \multicolumn{5}{|c|}{ Absorbance } \\
\hline & Inlet-1 & inlet-2 & center & $\begin{array}{l}\text { outlet-1 } \\
\end{array}$ & outlet-2 \\
\hline $\mathrm{Na}$ & 0.025 & 0.024 & 0.020 & 0.028 & 0.027 \\
\hline $\mathrm{Mg}$ & 0.54 & 0.57 & 0.50 & 0.53 & 0.52 \\
\hline $\mathrm{K}$ & 0.015 & 0.014 & 0.013 & 0.014 & 0.0135 \\
\hline $\mathrm{Ca}$ & 0.009 & 0.013 & 0.005 & 0.008 & 0.005 \\
\hline $\mathrm{Cr}$ & 0.0058 & 0.0053 & 0.0050 & 0.0058 & 0.0053 \\
\hline Co & 0.0130 & 0.0120 & 0.010 & 0.0159 & 0.0157 \\
\hline $\mathrm{Ni}$ & 0.010 & 0.012 & 0.0101 & 0.011 & 0.0109 \\
\hline $\mathrm{Mn}$ & 0.50 & 0.049 & 0.044 & 0.051 & 0.052 \\
\hline $\mathrm{Cu}$ & 0.013 & 0.0113 & 0.010 & 0.012 & 0.011 \\
\hline
\end{tabular}

\section{References}

[1] Kebede, N.; Bhagwan, S.; Chandravanshi and Taddese, W. (2010) Correlation among trace metals in tilapia (Oreochromis niloticus), sediment and water samples of lakes Awassa and Ziway, Ethiopia. Int. J. Biol. Chem. Sci., 4, 1641-1656.

[2] Ababu, T. (2005) Water quality monitoring in lake Abaya and lake Chamo region: A research based on water resources of the Abaya-Chamo basin - South Ethiopia, Ph.D. thesis, Siegen University, Germany.

[3] Essien, D. and Nsikak, U. (2006) Spatio-temporal distribution of heavy metals in sediment and surface water instubbs creek, Nigeria. Trends Applied Sci. Res., 3, 292-300.

[4] Akan, C. J.; Abdulrahman, I. F.; Sodipo, A. O.; Ochanya, E. A. and Askira, K. Y. (2010) Heavy metals in sediments from River Ngada. J. Environ. Chem. Ecotoxicol., 2, 131-140.

[5] Rashed, N. M. Biomarkers as indicator for water pollution with heavy metals in rivers, seas and oceans. Faculty of science, Aswan, south valley University, Egypt.

[6] Frank, M. (2009) Speciation of metals in natural waters. Rosentiel school of marine and atmospheric science, University of Miami, USA.

[7] Öztürk, M.; Özözen, G.; Minareci, O. and Minareci, E. (2009) Determination of heavy metals in fish, water and sediments of avsar dam lake in turkey. Iran J. Environ. Health. Sci. Eng., 6, 73-80.

[8] Indrajit, S.; Ajay, S. and Shrivastava, S. (2011) Study for determination of heavy metals in fish species of the river yamuna (Delhi) by inductively coupled plasma-optical emission spectroscopy (ICP-OES). Adv. Appl. Sci. Res., 2, 161-166.

[9] Mohamed, H. and Mohamed, R. (2005) Accumulation of trace metals in some benthic invertebrate and fish species relevant to their concentration in water and sediment of lake qarun, Egypt. Egypt J. Aqua. Res., 31, 290-301.

[10] Zerihun, D. (2008) Impact of fisheries and water quality changes on the management of Lake Chamo. A thesis submitted for the degree of Master of Science in Environmental science, M. Sc. thesis, Addis Ababa University.

[11] WHO (2004) Guidelines for drinking water quality, $3^{\text {rd }}$ ed., Geneva, Switzerland.

[12] Patil, S. G.; Chonle, S. G.; Jadhue, A. S and Raut, P. D. (2012) Res. J. Recent sci, 1, 56. 
[13] Tekle - Giorgis Y. (2000). Comparative age and growth assessment of the African catfish, clarias gariepinus Burchell (Clariidea) and Nile Perch, Lates niloticus linn. (Centropomidea) in the three southern Rift Valley lakes of Ethiopia, Lake Awasssa, Abaya and Chamo. PhD Thesis, Addis Ababa University, Addis Ababa.

[14] Eyasu Shumbulo, (2005). Phytoplankton biomass in relation to water quality in Lakes Abaya and Chamo, Ethiopia. Arbaminch University, Ethiopia.

[15] U.S. EPA. (U.S. Environmental Protection Agency). 1990. National water quality inventory. 1988 Report to Congress. Office of Water. U.S. Government Printing Office, Washington, D. C., USA.

[16] WHO (World Health Organization) (1993) Guidelines for drinking water quality, recommendation, Geneva: WHO.

[17] Sabata, B. C. and Nayar, M. P. (1995) River pollution in india; a case study of Ganza river, India, 33.

[18] BIS, Indian standard Drinking water Specification, Bureau of Indian Standard, (1990) Indian Standard.

[19] Elizabeth, K. (1996). Phytoplankton in an alkalinity-salinity series of Lakes in the Ethiopian Rift Valley. PhD Thesis, Uppsala University, Uppsala, Sweden.

[20] Demeke, A. (1998) Age and growth determination of tilapia, Oreochromis niloticus L. (Pisces: Cichlidea) in some lakes in Ethiopia. PhD Thesis, Addis Ababa University, Addis Ababa.
[21] FAO: Loffredo and Maldura (1941) Source book for the inland fisheries resource of Africa. 3. Rome.

[22] Wetzel, R. G. and Likens, G. E. (1991) Limnological analysis, $2^{\text {nd }}$ ed; Springer-verlag, New York.

[23] Bureau of Indian standards (BIS) guideline values for drinking water, 1991, India.

[24] Nayak, L. and Behora, D. P. (2004) Seasonal variation of same physic chemical parameters of the Chilika lagoon after opening the new month, India, Mar. Sci., 33, 206-208.

[25] Patel, A. C. and Patel, R. S. (2012) Comparison of physicchemical parameters of two lakes at Lodra and Nardipurumer biotic stress, Int. J. Sci. Res. Pub., 2, 1-7.

[26] Patra, A. P.; Patra, J. K; Mahapatra, N. K; Das, S. and Swain, G. C. (2010) Seasonal variation in physicochemical parameter of Chilika Lake after opening of new month, Orissa, India, World J. Fish mar. Sci., 2, 109-117.

[27] Bureau of Indian standards (BIS) guideline values for drinking water, 1998, India.

[28] Environmental protection agency, Ireland 2001. Parameters of water quality, interpretation and standards.

[29] WHO (world health organization) standards guidelines for drinking water, 2000.

[30] Trivedi, PR; Gurdeep, R. (1992). Environmental water and soil analysis. Akashdeep Publish. House, Delhi, India. pp. 141-152. 